\title{
Harrod syndrome
}

INSERM

\section{Source}

INSERM. (1999). Orphanet: an online rare disease and orphan drug data base. Harrod syndrome. ORPHA:2115

Harrod syndrome is characterized by the association of intellectual deficit, facial dysmorphism (a highly arched palate, pointed chin, and small mouth, hypotelorism, a long nose and large protruding ears), arachnodactyly, hypogenitalism (undescended testes and hypospadias) and failure to thrive. 